\title{
ISOLASI DAN IDENTIFIKASI BAKTERI PENDEGRADASI SELULOSA ASAL EKOSISTEM MANGROVE TUKAK SADAI, BANGKA SELATAN
}

\author{
Ardiansyah Kurniawan ${ }^{1,2}$, Dwi Febrianti ${ }^{1}$, Suci Puspita Sari ${ }^{1}$,Asep Awaludin \\ Prihanto $^{3}$, Euis Asriani ${ }^{1}$, Andi Kurniawan ${ }^{3}$, Abu Bakar Sambah ${ }^{3}$ \\ ${ }^{1}$ Dosen Fakultas Pertanian, Perikanan dan Biologi, Universitas Bangka Belitung. Merawang, Bangka, \\ Kep. Bangka Belitung Tel./Fax. +62-717-422145/421303email :ardian_turen@yahoo.co.id \\ ${ }^{2}$ Mahasiswa Doktoral Prodi Ilmu Perikanan dan Kelautan, Universitas Brawijaya \\ ${ }^{3}$ Dosen Fakultas Perikanan dan Ilmu Kelautan, Universitas Brawijaya.
}

\begin{abstract}
Agricultural waste has problems on fiber and cellulose digestibility in its utilization for aquaculture. The ability of plant cellulose degrading bacteria to become a source of energy can increase the digestibility of feed by fish. The purpose of this study was to identify the cellulolytic bacteria from the mangrove ecosystem, Tukak Sadai District, South Bangka Regency. This study was conducted in March until August 2017. Samples were taken from litter, mud and weathered wood and isolated using Carboxymetyl Cellulosa (CMC) $1 \%$ media and found 22 bacterial isolates. Gram staining results showed that 3 isolates (TSS 2, TSL 6 and TSK 4) were classified as gram positive and 19 other isolates were gram negative. Cellulolytic test results showed 6 isolates had the ability to degrade cellulase, namely 3 isolates from mangrove mud samples (TSS 1, TSL 7, TSL 1), 2 isolates from leaf litter (TSS 4, TSL 2) and 1 isolate from weathered wood (TSK 5). Sequencing of 16S rRNA gene DNA showed proximity to Pseudomonas aeruginosa in TSL 7 and TSS isolates 4.
\end{abstract}

Keywords: Cellulolytic Bacteria, Tukak Sadai Mangrove, 16 s rRNA

\begin{abstract}
ABSTRAK
Limbah pertanian memiliki kendala pada daya cerna serat dan selulosa pada pemanfaatannya dalam akuakultur. Kemampuan bakteri pendegradasi selulosa tumbuhan menjadi sumber energi dapat meningkatkan daya cerna pakan oleh ikan. Tujuan penelitian ini adalah untuk mengidentifikasi bakteri selulolitik asal ekosistem mangrove Kecamatan Tukak Sadai Kabupaten Bangka Selatan. Penelitian ini dilaksanakan pada bulan Maret hingga Agustus 2017. Sampel diambil dari serasah, lumpur dan kayu lapuk dan diisolasi menggunakan media Carboxymetyl Cellulosa (CMC) $1 \%$ dan didapatkan 22 isolat bakteri. Hasil pewarnaan gram menunjukkan 3 isolat (TSS 2, TSL 6 dan TSK 4) tergolong dalam gram positif dan 19 isolat lainnya merupakan gram negatif. Hasil uji selulolitik menunjukkan 6 isolat memiliki kemampuan mendegradasi selulase yaitu 3 isolat dari sampel lumpur mangrove (TSS 1, TSL 7, TSL 1), 2 isolat dari serasah daun (TSS 4, TSL 2) dan 1 isolat dari kayu lapuk (TSK 5). Sekuensing DNA gen 16S rRNA menunjukkan kedekatan dengan Pseudomonas aeruginosa pada isolat TSL 7 dan TSS 4.
\end{abstract}

Kata kunci : Bakteri Selulolitik, Mangrove Tukak Sadai, 16 s rRNA 


\section{PENDAHULUAN}

Bakteri selulolitik merupakan bakteri yang mampu mensekresikan enzim selulase. Selulase merupakan enzim ekstraseluler yang terdiri atas kompleks endo- $\beta-1,4-$ glukonase, ekso- $\beta$-1,4-glukonase dan $\beta-1,4$ glukosidase. Enzim yang disekresikan oleh bakteri selulolitik ini akan mendegradasi selulosa menjadi molekul monosakarida (Madigan et al, 2000). Bakteri selulolitik yang berkemampuan mensekresikan enzim selulase dapat dimanfaatkan dalam berbagai aplikasi industri salah satunya adalah sebagai degradator derat kasar bahan baku pakan ternak (Andriani et al, 2012).

Bakteri selulolitik secara alami umum dijumpai pada tanah pertanian, hutan mangrove, pada rabuk (pupuk) atau pada jaringan tanaman yang membusuk (Azizah, 2013). Hutan mangrove terdapat di sepanjang garis pantai di kawasan tropis, dan menjadi pendukung berbagai jasa ekosistem, termasuk produksi perikanan dan siklus unsur hara (Donato et al, 2012). Ekosistem hutan mangrove merupakan salah satu ekosistem yang memiliki produktivitas tinggi dibandingkan ekosistem lain. Dekomposisi bahan organik yang tinggi, menjadikan hutan mangrove sebagai tempat sumber makanan dan habitat berbagai biota seperti ikan, udang dan kepiting. Perombakan bahan organik pada ekosistem mangrove disebabkan oleh mikroorganisme yang mampu menghasilkan enzim ekstraseluler, seperti bakteri selulolitik (Wijiyono, 2009).

Bangka Belitung merupakan salah satu daerah yang memiliki kawasan hutan mangrove yang luas mencapai 273.692,81 hektar. Kawasan hutan mangrove terbesar di pulau Bangka terdapat di Kabupaten Bangka Selatan dengan luasan 58.165,04 hektar (Siburian dan Haba, 2016). Ditinjau dari luasan kawasan hutan mangrove tersebut, tentunya potensi bakteri selulolitik di daerah Bangka Selatan akan cenderung lebih besar di bandingkan dengan daerah lainnya. Berdasarkan kegunaan dari bakteri selulolitik dan potensi kawasan mangrove di daerah Bangka Selatan, maka penelitian ini dilakukan untuk mengidentifikasi bakteri selulolitik di salah satu lokasi di Bangka Selatan.

\section{TINJAUAN PUSTAKA}

Hutan mangrove merupakan komunitas vegetasi pantai tropis, yang didominasi oleh beberapa spesies pohon mangrove yang mampu tumbuh dan berkembang pada daerah pasang-surut pantai berlumpur sehingga ekosistem mangrove banyak ditemukan di pantai-pantai teluk yang dangkal, estuaria, delta dan daerah pantai yang terlindung (Bengen, 2002). Pada ekosistem mangrove terdapat biota yang berasosiasi dengan mangrove (biota darat dan laut, lumut kerak, cendawan, ganggang, bakteri dan lain-lain) baik yang hidupnya menetap, sementara, sekali-sekali, biasa ditemukan, kebetulan maupun khusus hidup di habitat mangrove (Santoso, 2006). Mangrove di Pulau Bangka memiliki pengaruh aktivitas penambangan timah (Sari dan Rosalina, 2014). Meskipun hutan mangrove dipulau Bangka mengalami penurunan akibat penambangan timah baik di darat maupun dilautan,sumberdaya dalam hutan mangrove masih memberikan dampak positif bagi kehidupan (Kurniawan et al, 2018)..

Bakteri memainkan peran penting dalam ekosistem mangrove terutama dalam mengurai searasah daun (Yahya et al, 2014).Bakteri dan fungi melakukan proses dekomposisi. Hasil daridekomposisi merupakan mineral dan unsur nutrienyang sangat dibutuhkan bagi ekosistem mangrove. Detritus yang dihasilkan menjadi makanan bagi invertebrata dan mempengaruhi rantai makanan bersama ikan dan crustacea lainnya (Dahuri et al., 2008).Kemampuan bakteri pendegradasi selulosa yang diperoleh dari alam diharapkan dapatbermanfaat untuk mendegradasi selulosa baik untuk keperluan industri maupun konservasi lingkungan (Heck et al., 2002). Serasah daun mangrove di 
Pulau Bangka memiliki potensi bakteri pendegradasi selulosa Bacillus subtilis, Staphylococcus saproviticus dan Bacillus cereus (Kurniawan et al, 2018).

\section{METODE}

Penelitian ini terlaksana pada bulan Maret - Mei 2017 dengan pengambilan sampel di mangrove Tukak Sadai, Kabupaten Bangka Selatan (Gambar 1) dan kultur hingga identifikasi bakteri selulolitik di Laboratorium Mikrobiologi, Universitas Bangka Belitung, Laboratorium Mikrobiologi, Fakultas Perikanan dan Ilmu Kelautan, Universitas Brawijaya dan Laboratorium Genetika, Departemen Biologi, Fakultas Sains dan Teknologi, Universitas Islam Negeri Maulana Malik Ibrahim Malang.

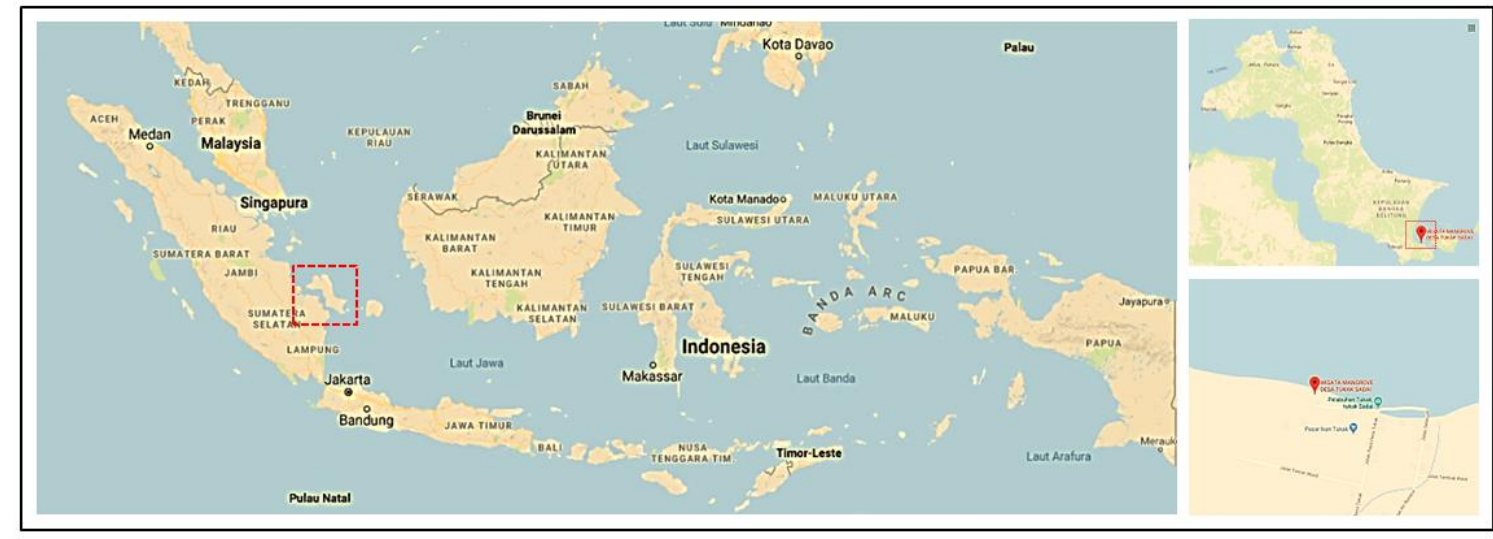

Gambar 1. Lokasi Pengambilan Sampel di Tukak Sadai, Kab. Bangka Selatan.

Penelitian ini merupakan jenis penelitian deskriptif-eksploratif, yaitu dengan mengambil seluruh isolate bakteri dari lumpur, serasah dan kayu lapuk di mangrove yang diisolasi dengan media selektif Carboxymetyl Cellulosa $(C M C)$. Sampel diambil di area Pasir Putih di Tukak Sadai, Bangka Selatan. Lumpur diambil dari beberapa titik, kemudian dikomposit menjadi satu. Sebanyak 1 gram lumpur, serasah daun dan kayu lapuk yang telah dihaluskan dimasukkan ke dalam media nutrien broth steril pada labu Erlemenyer $100 \mathrm{ml}$ dan dishaker selama 24 jam pada kecepatan $125 \mathrm{rpm}$. Tahap berikutnya adalah pengenceran bertingkat hingga $10^{-15}$ dan ditebar pada cawan petri yang berisi media agar steril yang selanjutnya diinkubasi selama 24 jam dengan suhu $37^{\circ} \mathrm{C}$. Isolasi bakteri selulolitik dilakukan dengan metode cawan gores pada media padat selulase yang mengandung $1 \% \mathrm{CMC}$ ( $1 \mathrm{~g} \mathrm{CMC} ; 0,02 \mathrm{~g} \mathrm{MgSO}_{4} .7 \mathrm{H}_{2} \mathrm{O} ; 0,075 \mathrm{~g} \mathrm{KNO}_{3}$; $0,002 \mathrm{~g} \mathrm{~K}_{2} \mathrm{HPO}_{4} ; 0,004 \mathrm{~g} \mathrm{CaCl}_{2} \cdot 2 \mathrm{H}_{2} \mathrm{O} ; 0,2 \mathrm{~g}$ ekstrak khamir; $1,5 \mathrm{~g}$ agar batang), diinkubasi pada suhu $37^{\circ} \mathrm{C}$ selama \pm 24 jam. Koloni tunggal yang tumbuh pada cawan petri tersebut diidentifikasi karakteristik makroskopis dan mikroskopisnya. Uji kualitatif selulolitik dilakukan dengan menggunakan kultur isolat pada medium agar yang diperkaya dengan 1\% CMC selama 72 jam dan ditetesi larutan congo red serta dilakukan pengamatan zona bening sebagai indikasi degradasi selulosa.

Isolat bakteri selulolitik terpilih di kultur pada media nutrient broth dan diinkubasi selama 3 hari untuk selanjutnya diidentifikasi dengan metode 16S rRNA. Isolasi DNA dilakukan dengan menggunakan prosedur Kit Isolasi DNA (Wizard of Genomic DNA Purification Kit dari Promega). Kemurnian terukur dan konsentrasi DNA yang diisolasi menggunakan spektrofotometer UV Biorad. Primer dirancang menggunakan perangkat lunak Oligo Analyzer versi 1.0.2., Oligo Explorer 1.1.0. dan BLAST (Basic Local Alignment Search Tool) yang bisa diakses online di NCBI. Amplifikasi gen genotip dilakukan dengan teknik Polymerase Chain Reaction atau PCR menggunakan mesin 
thermalcycler. Komposisi PCR dengan total volume $20 \mu \mathrm{l} /$ tube terdiri dari $6 \mu \mathrm{l}$ ddH2O, kit PCM $10 \mu \mathrm{l} \mathrm{GoTaq}{ }^{\circledR}$ Green Master Mix (buffer $10 \times$ taq polymerase, dNTP, $\mathrm{MgCl} 2$, primer, Taq DNA polymerase, ddH2O), $1 \mu$ f forward primer, sampel DNA terisolasi $1 \mu \mathrm{l}$ dan $2 \mu \mathrm{l}$ primer. Band yang paling kuat disekuensing menggunakan ABI PRISM ${ }^{\circledR} 310$ Genetic Analyzer. Penggabungan hasil sequencing forward dan reverse menggunakan software Bioedit. Pencarian database dilakukan melalui NCBI dengan BLAST.

\section{HASIL DAN PEMBAHASAN}

Hasil identifkasi bakteri selulolitik diisolasi dari sampel lumpur, kayu lapuk dan serasah daun mangrove Tukak Sadai, Bangka Selatan yaitu diperoleh 22 isolat bakteri. Skrining bakteri dapat dilihat pada Gambar 2. Bakteri yang telah diisolasi dikarakterisasi secara makroskopis meliputi warna, bentuk, ukuran, tepian, dan elevasi sebagaimana disajikan pada Tabel 1.
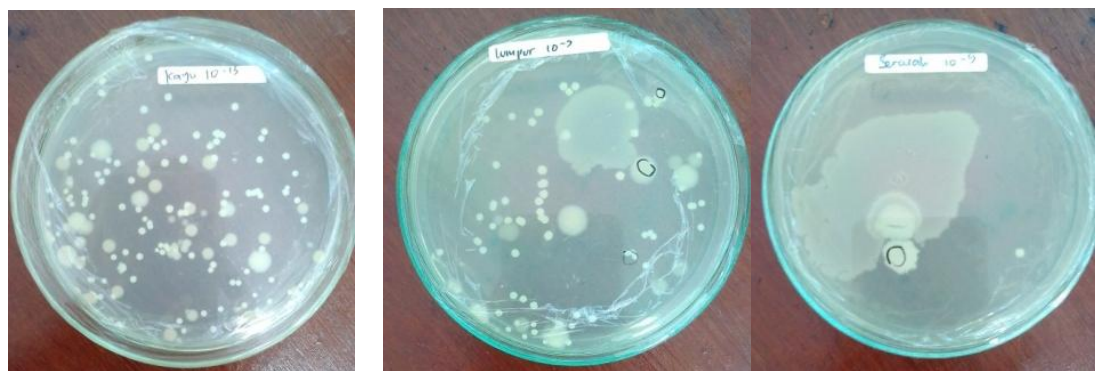

Gambar 2. Skrining bakteri selulolitik pada media agar CMC 1\% dari sampel kayu lapuk (kiri), sampel lumpur (tengah) dan sampel serasah daun.

Tabel 1. Karakteristik makroskopis isolat bakteri dari serasah daun, kayu lapuk dan lumpur.

\begin{tabular}{|c|c|c|c|c|c|c|}
\hline \multirow{2}{*}{ No } & \multirow{2}{*}{ Kode Isolat } & \multicolumn{5}{|c|}{ Karakteristik Koloni Bakteri } \\
\hline & & Warna & Bentuk & Ukuran & Tepian & Elevasi \\
\hline 1 & TSS 1 & Krem & Bulat & Besar & Rata & Datar \\
\hline 2 & TSS 2 & Krem & Takberaturan & Sedang & Tak beraturan & Datar \\
\hline 3 & TSS 3 & Krem & Bulat & Sedang & Datar & Datar \\
\hline 4 & TSS 4 & Krem & Bulat & Kecil & Datar & Datar \\
\hline 5 & TSS 5 & Krem & Bulat & Besar & Bergerigi & Cembung \\
\hline 6 & TSS 6 & Putih & Bulat & Kecil & Rata & Rata \\
\hline 7 & TSK 1 & Krem & Bulat & Titik & Rata & Rata \\
\hline 8 & TSK 2 & Krem & Bulat & Kecil & Rata & Rata \\
\hline 9 & TSK 3 & Putih & Bulat & Sedang & Rata & Rata \\
\hline 10 & TSK 4 & Putih & Bulat & Titik & Rata & Rata \\
\hline 11 & TSK 5 & Krem & Bulat & Besar & Rata & Rata \\
\hline 12 & TSK 6 & Krem & Bulat & Besar & Bergerigi & Cembung \\
\hline 13 & TSK 7 & Krem & Takberaturan & Sedang & Bergerigi & Cembung \\
\hline 14 & TSK 8 & Putih & Bulatberawan & Titik & Bergerigi & Cembung \\
\hline 15 & TSL 1 & Krem & Bulat & Besar & Bergerigi & Cembung \\
\hline 16 & TSL 2 & Krem & Bulat & Sedang & Datar & Datar \\
\hline 17 & TSL 3 & Krem & Bulat & Kecil & Datar & Datar \\
\hline 18 & TSL 4 & Krem & Bulat & Besar & Datar & Cembung \\
\hline 19 & TSL 5 & Krem & Bulat & Sedang & Datar & Datar \\
\hline 20 & TSL 6 & Krem & Bulatbergerigi & Kecil & Bergerigi & Datar \\
\hline 21 & TSL 7 & Krem & Takberaturan & Besar & Tak beraturan & Cembung \\
\hline 22 & TSL 8 & Krem & Bulat & Besar & Rata & Rata \\
\hline
\end{tabular}


Kemampuan isolat bakteri yang tumbuh pada media agar yang di perkaya CMC mengindikasikan bahwa bakteri tersebut mampu memanfaatkan selulosa sebagai salah satu nutrien terutama sebagai sumber karbon. Besar kecilnya zona bening yang dihasilkan menunjukkan potensi bakteri selulolitik dalam proses dekomposisi selulosa. Isolat bakteri selulolitik potensial diperoleh dengan indikasi membentuk zona bening terluas dan kecerahan yang terbentuk. Luas zona bening tergantung pada konsentrasi CMC dan agar yang digunakan (Meryandini et al, 2009). Semakin banyak CMC dan agar yang digunakan semakin tinggi kepadatan medium. Semakin tinggi konsentrasi agar, semakin kecil pori medium sehingga enzim selulase yang disekresikan lebih sulit melewati pori tersebut dan mengakibatkan terhambatnya proses degradasi (Hankin dan Anagnostakis, 1997).

Pada 22 isolat bakteri yang teridentifikasi dilakukakan karakterisasi secara mikroskopis dengan pewarnaan gram. Hasil pewarnaan gram menunjukkan 3 isolat bakteri yang tergolong gram positif yaitu TSL 6, TSS 2 dan TSK 4.19 isolat bakteri lainnya tergolong ke dalam Gram negatif. Bakteri gram positif ditandai dengan berwarna ungu ketika diamati menggunakan mikroskop, sedangkan gram negatif cenderung berwarna merah muda. Hasil pewarnaan gram dapat dilihat pada Tabel 2.

Tabel 2. Hasil Uji Pewarnaan Gram dan Uji Kualilatif Selulolitik Terhadap Isolat Bakteri Dari Lumpur, Serasah Daun Dan Kayu Lapuk Mangrove Tukak Sadai

\begin{tabular}{|c|c|c|c|c|c|}
\hline \multirow{2}{*}{ No } & \multirow{2}{*}{$\begin{array}{l}\text { Kode } \\
\text { Isolat } \\
\end{array}$} & \multicolumn{3}{|c|}{ Karakteristik Koloni Bakteri } & \multirow[b]{2}{*}{ Aktifitas Selulolitik } \\
\hline & & Warna & Bentuk & Jenis Bakteri Gram & \\
\hline 1 & TSS 1 & Merah & Bulat & Negatif & + \\
\hline 2 & TSS 2 & Ungu & Batang & Positif & - \\
\hline 3 & TSS 3 & Merah muda & Batang & Negatif & - \\
\hline 4 & TSS 4 & Merah muda & Bulat & Negatif & + \\
\hline 5 & TSS 5 & Merah muda & Bulat & Negatif & - \\
\hline 6 & TSS 6 & Merah muda & Bulat & Negatif & - \\
\hline 7 & TSK 1 & Merah muda & Bulat & Negatif & - \\
\hline 8 & TSK 2 & Merah muda & Bulat & Negatif & - \\
\hline 9 & TSK 3 & Merah muda & Batang & Negatif & - \\
\hline 10 & TSK 4 & Ungu & Bulat & Positif & - \\
\hline 11 & TSK 5 & Merah muda & Bulat & Negatif & + \\
\hline 12 & TSK 6 & Merah & Bulat & Negatif & - \\
\hline 13 & TSK 7 & Merah muda & Bulat & Negatif & - \\
\hline 14 & TSK 8 & Merah muda & Bulat & Negatif & - \\
\hline 15 & TSL 1 & Abu-abu & Bulat & Negatif & + \\
\hline 16 & TSL 2 & Merah muda & Batang & Negatif & + \\
\hline 17 & TSL 3 & Merah muda & Bulat & Negatif & - \\
\hline 18 & TSL 4 & Merah & Bulat & Negatif & - \\
\hline 19 & TSL 5 & Merah muda & Bulat & Negatif & - \\
\hline 20 & TSL 6 & Ungu & Batang & Positif & - \\
\hline 21 & TSL 7 & Merah & Bulat & Negatif & + \\
\hline 22 & TSL 8 & Merah & Bulat & Negatif & - \\
\hline
\end{tabular}

Keterangan. : + : zona bening lebih luas, + : sedikit zona benih, - : tidak ada zona bening.

Isolat TSL 6, TSS 2 dan TSK 4 tergolong bakteri Gram positif, hal ini ditandai dengan morfologi bakteri yang berwarna ungu setelah diberikan zat pewarna. Bakteri Gram positif merupakan bakteri yang dapat menahan kompleks pewarna primer ungu 
kristal iodium sampai akhir prosedur dan sel bakteri akan berwarna biru gelap atau ungu. Bakteri Gram negatif merupakan bakteri yang kehilangan kompleks ungu kristal pada waktu pembilasan dengan alkohol, namun kemudian terwarnai dengan pewarna tandingan yaitu safranin sehingga sel - sel tampak berwarna merah muda pada akhir pewarnaan. Bakteri Gram negatif memiliki struktur dinding sel dengan lapisan peptidoglikan yang tipis dan kadar lipid yang tinggi dibanding bakteri gram positif. Pada pewarnaan gram, kandungan lipid yang tinggi pada membran sel bakteri Gram negatif dapat larut dengan penambahan alkohol, sehingga menyebabkan permeabilitas membran sel menjadi lebih besar. Hal ini mengakibatkan pewarna utama yang membentuk kompleks kristal-iodin pada permukaan sel menjadi mudah terlepas dan membran sel bakteri Gram negatif menjadi bening. Sehingga saat diberi safranin sebagai warna penutup, dinding sel bakteri Gram negatif akan menyerap safranin dan menyebabkan sel bakteri gram negatif berwarna merah (Pelczardan Chan, 2007).

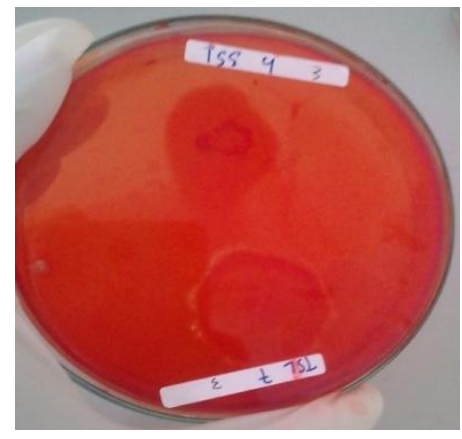

Gambar 3. Uji kualitatif aktivitas enzim selulase dengan pewarna congo red.

Berdasarkan Tabel 2, terdapat 6 isolat yang positif uji aktivitas enzim selulase. Hasil positif ditandai dengan adanya zona bening disekitar koloni setelah ditetesi dengan larutan congo red. Isolat TSS 4 dan TSL 7 memiliki zona bening yang lebih besar dibandingkan keempat isolat lainnya. Hal ini menandakan kemampuan mensekresikan enzim selulase dari kedua isolat tersebut lebih tinggi dibandingkan isolat yang lain.Selulosa yang terdapat pada media CMC akan habis diserap oleh bakteri selulolitik sehingga saat pewarnaan menggunakan reagen congo red terdapat zona bening karena tidak terdapat ikatan antara selulosa dan congo red, sedangkan pada daerah yang masih terdapat selulosa akan berikatan dengan reagen congo red dan media nampak berwarna merah (Sinatryani, 2014). Zona bening yang terbentuk terkait dengan kelarutan dari enzim selulase. Semakin tinggi tingkat kelarutan suatu enzim maka akan semakin besar zona bening yang terbentuk. Diameter zona bening umumnya berukuran lebih besar dibandingkan dengan diameter koloni, karena enzim selulase disekresikan ke lingkungan sekitarnya oleh bakteri pendegradasi selulosa. Bakteri tidak dapat memasukkan molekul selulosa, karena ukuran selulosa lebih besar daripada ukuran sel bakteri (Zverlovaet al, 2003). Bakteri selulolitik sering diisolasi dari tanah yang mengandung serasah daun. Hal ini disebabkan karena tanah mengandung bahan organik yang relatif kaya dan terdapat serasah daun dengan kandungan polisakarida yang relatif komplek. Kondisi tersebut menyebabkan tanah dan serasah daun menjadi habitat yang baik untuk berbagai mikroorganisme (Williamdan Govind, 2003).

Isolat bakteri dengan kemampuan degradasi selulosa diidentifikasi kedekatan spesiesnya melalui sekuensing DNA gen 16S rRNA. Hasil sekuensing forward dan reserve yang di identifikasi menggunakan software bioedit menunjukkan kedekatan dengan Pseudomonas aeruginosa pada isolat TSL 7 dan TSS 4. Pseudomonas 
aeruginosa juga ditemukan pada sedimen mangrove cagar alam Hongkong (Bo Yinet al, 2005),mangrove Avicennia marina yang berasal dari Pantai Bajul Mati, Malang, Jawa Timur (Fatchiyah, 2017) dan ekosistem mangrove pulau Great Nicobar, India (Kothamasi, 2006).

\section{KESIMPULAN DAN SARAN}

Penelitian identifikasi bakteri selulolitik dengan sampel serasah, lumpur dan kayu lapuk dari mangrove Tukak Sadai, Bangka Selatan didapatkan 22 isolat bakteri yang menunjukkan 3 isolat (TSS 2, TSL 6 dan TSK 4) tergolong dalam gram positif dan 19 isolat lainnya merupakan gram negatif. Hasil uji selulolitik menunjukkan 6 isolat memiliki kemampuan mendegradasi selulase yaitu 3 isolat dari sampel lumpur mangrove (TSS 1, TSL 7, TSL 1), 2 isolat dari serasah daun (TSS 4, TSL 2) dan 1 isolat dari kayu lapuk (TSK 5). Isolat TSL 7 dan TSS 4 memiliki kemampuan degradasi selulosa lebih besar menunjukkan kedekatan dengan Pseudomonas aeruginosa. Hasil penelitian memerlukan analisa lanjutan pada uji patogenitas dan aplikasi sebagai biodegradator selulosa untuk mengetahui potensi pemanfaatannya pada bidang perikanan.

\section{UCAPAN TERIMAKASIH}

Penulis menyampaikan terimakasih kepada Direktorat Jendral Pendidikan Tinggi Kemenristekdikti atas Pembiayaannya dalam Hibah Kerjasama Perguruan Tinggi antara Universitas Bangka Belitung dan Universitas Brawijaya tahun 2017 - 2018 dan tenaga teknis mahasiswa Universitas Bangka Belitung dan mahasiswa Universitas Brawijaya yang membantu pelaksanaan penelitian baik di lapangan maupun di laboratorium.

\section{DAFTAR PUSTAKA}

Andriani Y, S. Sastrawibawa, R. Safitri, Abun. Isolasi Dan Identifikasi Mikroba Selulolitik Sebagai BiodegradatorSerat Kasar Dalam Bahan Pakan Dari Limbah Pertanian. IJAS Vol. 2 Nomor 3. 2012

Azizah, S.N.. Skrining Bakteri Selulolitik Asal Vermicomposting Tandan Kosong Kelapa Sawit. Skripsi. Fakultas Matematika Dan Ilmu Pengetahuan AlamUniversitas Jember. 2013

Bengen, D. G. 2002. Ekosistem dan Sumberdaya Alam Pesisir. Pusat Kajian Sumberdaya Pesisir dan Lautan. Fakultas Perikanan dan Ilmu Kelautan. Institut Pertanian Bogor. Bogor

Bo Yin, Ji-Dong Gu, NianshengWan. Degradation of indole by enrichment culture and Pseudomonas aeruginosa Gs isolated from mangrove sediment. International Biodeterioration \& Biodegradation Volume 56, Issue 4. 2005

Dahuri, R., Rais, J., Ginting, S.P. \& Sitepu. 2008. Pengelolaan Sumber Daya Wilayah Pesisir dan Lautan Secara Terpadu. PT. Pradnya Paramita.Jakarta.

Donato Daniel C., J. Boone Kauffman, Daniel Murdiyarso, Sofyan Kurnianto, Melanie Stidham dan Markku Kanninen. Mangrove adalah salah satu hutan terkaya karbon di kawasan tropis. Brief CIFOR. No 12. 2012

Fatchiyah. A. Isolasi dan Identifikasi Bakteri Endofit Mangrove Api-Api Putih (Avicennia marina) Penghasil enzim L-asparaginase. Tesis. Manajemen Sumberdaya Perairan. Universitas Brawijaya. 2017.

Hankin, L., dan S.L. Anagnostakis. Solid media containing carboxymethylcellulose to detect Cx cellulase activity of microorganisms. Journal of General Microbiology. 98. 1997. 
Heck JX. Plinho FH. Marco AZA. 2002. Cellulase and xylanase production by isolated amazon bacillus strain using soybean industrial residue based solid state cultivation. Brazil J Microbiol 33

Kothamasi D, S. Kothamasi, A. Bhattacharyya, R Kuhad, C. R. Babu. Arbuscular Mycorrhizae And Phosphate Solubilising Bacteria Of The Rhizosphere Of The Mangrove Ecosystem Of Great Nicobar Island, India. Biol Fertil Soils 42. 2006

Kurniawan, A., Prihanto, A.A., Puspita, S., Kurniawan, A., Asriani, E., Sambah, A.B. 2018. Bakteri Selulolitik Serasah Daun Mangrove Di Pulau Bangka. Samakia: Jurnal Ilmu Perikanan. Vol. 9 No.1

Madigan M.T., Martinko J.M. and Parker J. Biology of Microorganisms. $9^{\text {th }}$ Edition. New Jersey: Prentice Hall. Page 1102. 2000.

Meryandini, A., W. Widosari, B. Maranatha, T.C. Sunarti, N. Rachmania dan H. Satria. Isolasi Bakteri Selulolitik dan Karakter Enzimnya. Jurnal Makara Sains. Vol. 13. No 1. 2009.

Pelczar, M. J. dan Chan, E. C. S. Dasar-Dasar Mikrobiologi. Terjemahan Hadioemoto, R.S., Imas, T., Jitromo, S.S., dan Angka, S.L. Elements of Microbiology. UI Press. Jakarta. 2007.

Santoso, N. 2006. Pengelolaan Ekosistem Mangrove Berkelanjutan di Indonesia. Dalam bahan pelatihan. 2006. "Training Workshop on Developing The Capacity of Environmental NGOs in Indonesia to Effeticvely Implement Wetland Project According to the Ramsar Guidelines and Obyectives of the Convention on Biodiversity". Bogor.

Sari, S. P., dan Rosalina, D. 2014. Tingkat Keberhasilan Penanaman Mangrove pada Lahan Pasca Penambangan Timah di Kabupaten Bangka Selatan. Maspari Journal, Vol. 6, No. 2.

Siburian, R dan J. Haba. Konservasi Mangrove dan Kesejahteraan Masyarakat. Yayasan Pustaka Obor Indonesia. Jakarta. 2016.

Sinatryani, D. Kelimpahan Bakteri Selulolitik Di Muara Sungai Gunung Anyar Surabaya dan Bancaran Bangkalan. Skripsi. Fakultas Perikanan dan Kelautan. Universitas Airlangga, Surabaya. 2014.

Wijiyono. Keanekaragaman Bakteri Serasah Daun Avicenia Marina yang Mengalami Dekomposisi pada Berbagai Tingkat Salinitas di Teluk Tapian Naupli. Tesis. Sekolah Pasca Sarjana Universitas Sumatera Utara, Medan. 2009.

William, R. dan N.S. Govind. Identification of carbohydrate degading bacteria in subtropical regions. Rev. Biol. Trop. 51, Supl. 4. 2003.

Yahya, Happy Nursyam, Yenny Risjani, dan Soemarno. 2014. Karakteristik Bakteri di Perairan Mangrove Pesisir Kraton Pasuruan. ILMU KELAUTAN Vol. 19. No.1.

Zverlova, V. V., W. Holl, dan H. Schwarz. Enzymes for digestion of cellulose and other polysaccharides in the gut of longhorn beetle larvae, Rhagium inquisitor L. (Col., Cerambycidae). International Biodeterioration \& Biodegadation. 51. 2003. 